\title{
KARAKTERISTIK DIAGNOSIS PASIEN TUBERKULOSIS PARU DI RUMAH SAKIT GRANDMED TAHUN 2019
}

\author{
Aris Josua Mahulae ${ }^{1}$ Suandy ${ }^{2}$ \\ 1,2Program Studi Pendidikan Dokter, Fakultas Kedokteran, Universitas Prima Indonesia \\ Arisjosua94@gmail.com
}

\begin{abstract}
Abstrak
Tuberkulosis paru (TB) merupakan penyakit saluran pernapasan yang disebabkan bakteri Mycobacterium tuberculosis, Kuman tersebut merupakan genus Actinomycetales dan family dari Mycobacteriacea yang juga dikenal sebagai bakteri tahan asam. Tujuan dari penelitian ini untuk mengetahui Karakteristik Diagnosa dan Penyakit Penyerta Pasien Tuberkulosis di RS Grandmed Lubuk Pakam Tahun 2019. Penelitian ini dibuat dengan metode design studi kasus yang bersifat deskriptif retrospektif, besar sampel 100 data rekam medis pasien diambil secara purposive sampling, yaitu rekam medis yang paling datanya dan dianalisa dengan deskriptif statistik. Berdasarkan hasil, ditemukan Umur termuda yaitu 17 tahun dan umur tertua 72 tahun, dengan jumlah laki-laki sebanyak 66 orang dan perempuan sebanyak 34 orang. Keluhan batuk >2 minggu (100\%) ditemukan pada semua pasien tuberkulosis paru, keluhan tambahan terbanyak adalah berkeringat malam hari (69\%) dan hasil pemeriksaan penunjang didapatkan pemeriksaan BTA terbanyak yaitu Positif $1(33 \%)$ diikuti dengan hasil pemeriksaan rontgen thoraks terbanyak adalah lesi minimal (46\%) serta penyakit penyerta mayoritas diabetes (17\%). Kesimpulan yang bisa didapatkan ialah distribusi terjadinya tuberkulosis paru lebih tinggi pada laki-laki (66\%) daripada perempuan (34\%) dan keluhan batuk >2 minggu ditemukan pada semua pasien tuberkulosis paru, serta pada pemeriksaan penunjang BTA mayoritas adalah positif 1 (33\%) dan pada pemeriksaan ronthen thoraks lesi minimal (46\%) yang terbanyak serta Penyakit Penyerta Diabetes (17\%) mayoritas dialami pasien tuberkulosis paru.
\end{abstract}

Kata Kunci : Tuberkulosis, Karakteristik, Diagnosis

\begin{abstract}
Pulmonary tuberculosis (TB) is a respiratory disease caused by the bacterium Mycobacterium tuberculosis. The germ is a genus of Actinomycetales and the family of Mycobacteriacea which is also known as acid-resistant bacteria. The purpose of this study was to determine the diagnostic characteristics and comorbidities of tuberculosis patients at Grandmed Lubuk Pakam Hospital in 2019. This study was made using a retrospective descriptive case study design method, with a sample size of 100 patient medical record data taken by purposive sampling, namely medical records most data and analyzed with descriptive statistics. Based on the results, it was found that the youngest age was 17 years and the oldest was 72 years old, with 66 men and 34 women. Complaints of cough> 2 weeks $(100 \%)$ were found in all pulmonary tuberculosis patients, the most additional complaints were night sweats (69\%) and the results of the supporting examinations found the most BTA examinations, namely Positive $1(33 \%)$ followed by the most chest X-ray examination results were minimal lesions (46\%) and comorbidities in the majority of diabetes (17\%). The conclusion that can be obtained is the distribution of pulmonary tuberculosis is higher in men (66\%) than women (34\%) and complaints of cough> 2 weeks were found in all pulmonary tuberculosis patients, and on the investigation of AFB the majority were positive 1 (33\%). ) and on thoracic examination, the most minimal lesions (46\%) and Complementary Diabetes (17\%) were experienced by pulmonary tuberculosis patients.

Keywords:

Tuberculosis,

Characteristics,

Diagnosis
\end{abstract}



Vol. 5/No.4 /Oktober 2020; ISSN:2502-731X

\section{PENDAHULUAN}

Penyakit tuberkulosis (TB) merupakan penyakit saluran nafas yang disebabkan oleh kuman Mycobacterium tuberculosis. Kuman tersebut merupakan genus Actinomycetales dan family dari Mycobacteriacea yang juga dikenal sebagai bakteri tahan asam (1) .Penyakit tuberculosis (TB) memiliki sumber penularan utama yaitu pasien tuberkulosis BTA positif Ketika bersin atau batuk. Penularan terjadi melalui udara dalam bentuk percikan dahak (droplet), terdapat sekitar 3000 percikan dahak yang dihasilkan dalam sekali batuk, kemudian kuman menyebar di udara dan infeksi terjadi ketika kuman tersebut di hirup lalu masuk kedalam saluran pernapasan ${ }^{(2)}$.

Berdasarkan data World Health Organization (WHO), pada tahun 2014 setidaknya terdapat 9,6 juta orang yang terinfeksi dan 1,2 juta orang diantaranya meninggal akibat tuberkulosis, namun di tahun 2016 telah terjadi peningkatan prevalensi penderita tuberkulosis mejadi 10,4 juta setidaknya terjadi 140 kasus per 100.000 penduduk, penyebarannya meliputi 3\% Kawasan amerika dan eropa, 7\% di Kawasan mediterania timur, 17\% di Kawasan pasifisik barat, 25\% di Kawasan afrika dan $45 \%$ di Kawasan asia selatan dan menurut laporan WHO pada tahun 2017, Indonesia menduduki urutan kedua di dunia dengan penderita TB terbanyak setelah india dengan jawa barat menjadi urutan teratas penemuan kasus penderita TB paru BTA positif baru dengan kasus baru sebanyak 22.583 dengan prevalensi kasus baru sebesar 647 per 100.000 penduduk $^{(3,4)}$.

Di Sumatera Utara ditahun 2017 dari 33 kabupaten kota kasus baru Tuberkulosis positif tertinggi adalah Medan sebanyak 5206 kasus, Deli Serdang sebanyak 2090 kasus, Langkat sebanyak 850 kasus dan untuk kasus paling rendah tejadi di Pakpak sebanyak 77 kasus ${ }^{(5)}$. Tuberkulosis sering sekali terlambat didiagnosa akibat dari beberapa faktor mulai dari fasilitas yang tidak memadai, prosedur yang salah, lingkungan dan pengetahuan pasien sendiri tentang penyakit $\mathrm{TB}^{(6)}$.

Diagnosis tuberkulosis berdasarkan Permenkes RI tahun 2016 di tetapkan berdasarkan (1) keluhan, (2) hasil anamnesis, (3) pemeriksaan fisik : yaitu keluhan utama batuk berdahak selama 2 minggu atau lebih dan di ikuti dengan dahak bercampur darah dengan keluhan tambahan sesak nafas, nafsu makan menurun, badan lemas dan berkeringat di malam hari , (4) pemeriksaan laboratorium meliputi pemeriksaan dahak sewaktu-pagi dan pemeriksaan tes cepat molekuler (TCM) TB. Tata cara diagnosa pasien TB paru sudah diketahui dan tertuang dalam peraturan Permenkes RI tahun 2016, namun seiring dengan perkembangan ilmu kedokteran dan majunya teknologi, maka tata cara tersebut dapat saja berubah seseuai dengan kondisi perubahan tempat dan waktu, sehubungan dengan itu maka timbul pertanyaan bagaimana tata cara diagnosa pasien TB paru di RS GrandMed? Oleh karena itu maka perlu dilakukan Penelitian gambaran diagnostik pasien penderita TB paru yang di rawat jalan maupun di rawat inap di RS GrandMed tahun $2019^{(7)}$

\section{METODE}

Penelitian dilaksanakan dengan desain studi kasus yang bersifat deskriptif dan retrosepktif. Penelitian ini berdasarkan pada data rekam medis terkait gambaran diagnosa dan penyakit penyerta pasien tuberkulosis paru di rumah sakit Grandmed tahun 2019. Penelitian ini dilakukan di bagian rekam medik Rumah Sakit Grandmed yang terletak di jalan medan Km 25 lubuk pakam, Sumatera Utara.Total sampel yang diperlukan minimal 100 data rekam medis pasien positif tuberkulosis paru yang dirawat di RS Grandmed Tahun 2019. Metode pengumpulan data yang di gunakan yaitu dengan cara purposive sampling berupa rekam medis yang datanya paling lengkap. Analisa data menggunakan program SPSS dan kemudian data dianalisis dengan cara deskriptif statistik distribusi proporsi dan kemudian disajikan dalam bentuk berupa narasi, tabel distribusi proporsi dan gambar (batung dan pie).

\section{HASIL DAN PEMBAHASAN}

Penelitian ini dilaksanakan demi mengetahui karakteristik diagnosa dan penyakit penyerta pasien tuberkulosis paru di Rumah Sakit Grandmed Lubuk Pakam Tahun 2019. Banyak sampel yang digunakan sebanyak 100 sampel dengan metode penelitian desain studi kasus deskriptif retrospektif yang diambil secara purposive sampling.

Hasil penelitian berdasarkan umur didapatkan usia termuda 17 tahun dan umur tertua usia 72 tahun dengan sex ratio $66 / 34 \times 100 \%=194.1 \%$ dengan jumlah laki-laki 66 orang dan perempuan 34 orang. Dari kelompok umur terbanyak diusia 33-40 tahun (30\%) dengan jumlah laki-laki (19\%) dan jumlah perempuan (11\%).

Umur yang terbanyak berada di usia 33-40 Tahun (30\%), usia 25-32 Tahun (24\%), usia 41-48 (14\%), usia 17-24 Tahun (11\%), usia 49-56 (8\%), usia 57-64 (7\%) dan usia yang paling sedikit usia 65-72 tahun (6\%).

Distribusi proporsi pasien tuberkulosis paru berdasarkan jenis kelamin dan umur yang dirawat di RS Grandmed Lubuk Pakam Tahun 2019 dapat dilihat pada table 1. 
Jurnal Ilmiah Mahasiswa Kesehatan Masyarakat Vol. 5/No.4 /Oktober 2020; ISSN:2502-731X

Tabel 1. Distribusi Proporsi Pasien Tuberkulosis Paru Berdasarkan Umur dan Jenis Kelamin yang di rawat di RS Grandmed Lubuk Pakam Tahun 2019.

\begin{tabular}{ccccccc}
\hline & \multicolumn{2}{c}{ Laki-laki } & \multicolumn{3}{c}{ Perempuan } & \multicolumn{2}{c}{ Jumlah } \\
\hline $\begin{array}{c}\text { Umur } \\
\text { (Tahun) }\end{array}$ & $\mathbf{F}$ & $\%$ & $\mathbf{F}$ & $\%$ & $\mathbf{F}$ & $\%$ \\
\hline $17-24$ & 7 & 7 & 4 & 4 & 11 & 11 \\
\hline $25-32$ & 15 & 15 & 9 & 9 & 24 & 24 \\
\hline $33-40$ & 19 & 19 & 11 & 11 & 30 & 30 \\
\hline $41-48$ & 9 & 9 & 5 & 5 & 14 & 14 \\
\hline $49-56$ & 7 & 7 & 1 & 1 & 8 & 8 \\
\hline $57-64$ & 5 & 5 & 2 & 2 & 7 & 7 \\
\hline $65-72$ & 4 & 4 & 2 & 2 & 6 & 6 \\
\hline Total & $\mathbf{6 6}$ & $\mathbf{6 6}$ & $\mathbf{3 4}$ & $\mathbf{3 4}$ & $\mathbf{1 0 0}$ & $\mathbf{1 0 0}$ \\
\hline
\end{tabular}

Hasil dari penelitian ini sesuai dengan kepustakaan dimana laki-laki cenderung memilki resiko lebih tinggi terkena penyakit tuberkulosis dibandingkan perempuan akibat dari faktor kebiasaan gaya hidup laki-laki seperti merokok dan meminum alkohol dibandingkan wanita. Kebiasaan merokok dan meminum alkohol tersebut dapat menurunkan imunitas tubuh dan memperbesar resiko untuk terkena tuberkulosis paru ${ }^{(8)}$.

Hasil penelitian ini sejalan dengan penelitian yang dilakukan oleh Setyo Dwi Widyastuti dkk, dimana didapati jenis kelamin tertinggi menderita tuberkulosis paru adalah laki-laki $67 \%$ dan perempuan 33\%, serta Usia 15-65 (96,6\%) merupakan resiko usia tertinggi yang sejalan dengan hasil peneltian ini yaitu usia 17-64 Tahun $(94 \%)^{(9)}$.

Distribusi proporsi pasien tuberkulosis paru berdasarkan keluhan utama didapatkan hasil (100\%) batuk >2 minggu. gejala ini timbul akibat dari rangsangan pada bronkus karena adanya iritasi, batuk diperlukan untuk mengeluarkan sisa- sisa radang. Sifat batuk di mulai dari batuk kering lalu secara perlahan timbul peradangan dan kemudian menghasilkan sputum

Hasil dari peneltian ini sejalan dengan yang hasil yang didapat oleh Eni Yulvia Susilanyanti dkk, tentang profil penderita penyakit tuberkulosis paru BTA positf yang ditemukan di BP4 lubuk Alung periode Januari 2012-Desember 2012, dimana hasilnya gejala utama pada pasien adalah batuk lebih dari 2 minggu, diketahui distribusi nya sebesar $99 \%{ }^{(10)}$.

Hasil ini juga di dukung oleh penelitian yang di lakukan oleh Ramalia Mohamad dkk, tentang diagnostik Mycobacterium tuberculosis pada penderita batuk $\geq 2$ minggu dengan pewarnaan Ziehl-Neelsen di Puskesmas Ranomuut dan
Puskesmas Kombos Manado, dimana didapatkan hasil distribusi $84 \%{ }^{(11)}$.

Distribusi proporsi pasien tuberkulosis paru dengan keluhan tambahan kombinasi bisa dilihat pada tabel2.

Tabel 2. Distribusi Proporsi Pasien Tuberkulosis Paru Berdasarkan Keluhan Tambahan Kombinasi yang di rawat di RS Grandmed Tahun 2019.

\begin{tabular}{lcc}
\hline \multicolumn{1}{c}{ Keluhan Tambahan Kombinasi } & F & \% \\
\hline $\begin{array}{l}\text { Demam + Berkeringat Malam Hari }+ \\
\text { Penurunan Berat Badan }\end{array}$ & 37 & 37 \\
\hline $\begin{array}{l}\text { Batuk Berdarah + Berkeringat Malam } \\
\text { Hari + Sesak Napas }\end{array}$ & 32 & 32 \\
\hline $\begin{array}{l}\text { Demam + Penurunan Berat Badan + } \\
\text { Sesak Napas }\end{array}$ & 25 & 25 \\
\hline Demam + Penurunan Berat Badan & 6 & 6 \\
\hline Total & $\mathbf{1 0 0}$ & $\mathbf{1 0 0}$ \\
\hline
\end{tabular}

Hal ini sesuai dengan teori yang telah disebutkan pada pedoman nasional pengangulangan TB, yang menyebutkan gejala tambahan pada pasien tuberculosis antara lain berkeringat malam hari, Demam, Penurunan Berat Badan, Sesak Napas dan Batuk Berdarah ${ }^{(7)}$.

Hasil dari penelitian ini juga sejalan dengan penelitian yang dilakukan oleh Aenah Mardiah tentang skrining tuberculosis paru di kabupaten banyumas provinsi jawa tengah. Pada penelitian yang dilakukan oleh Aenah Mardiah, didapati gejala tambahan pasien yang datang dengan keluhan berkeringat malam hari (75\%), demam sub febris (72\%), penurunan berat badan $(61 \%)$, sesak napas (50\%) dan batuk berdarah (33\%) ${ }^{(12)}$.

Distribusi proporsi pasien tuberkulosis paru berdasarkan pemeriksaan BTA bisa diliat pada gambar 1.

\section{Sputum BTA}

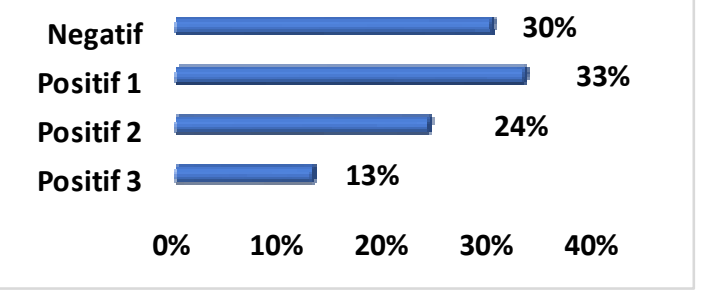

Gambar 1. Diagram Bar Distribusi Proporsi pasien DHF Berdasarkan Pemeriksaan BTA yang Dirawat di RS Grandmed Tahun 2019.

Hasil dari pemeriksaan ini juga sejalan dengan yang dilakukan oleh Mulyadi dkk, dimana mayoritas hasil pemeriksaan BTA pada pasien tuberkulosis 
Jurnal Ilmiah Mahasiswa Kesehatan Masyarakat Vol. 5/No.4 /Oktober 2020; ISSN:2502-731X

paru adalah BTA +1 (44,1\%), BTA + (20,6\%), BTA +3 $(20,6 \%)$ dan negatif $(14,7 \%)^{(13)}$.

Pada penelitian yang dilakukan oleh Nova Triandini dkk tentang Hubungan Hasil Pemeriksaan Sputum Basil Tahan Asam dengan Gambaran Luas Lesi Radiologi Tuberkulosis Paru di Rumah Sakit Al Islam Bandung didapatkan hasil yang sejalan dengan peneltian ini, dimana hasil dari pemeriksaan BTA tuberkulosis paru mayoritas BTA+1 (22,8\%), BTA +2 (20,8\%), BTA +3 (22,7\%) dan untuk Sputum BTA Negatif $(33,7 \%)^{(14)}$.

Distribusi proporsi pasien tuberkulosis paru berdasarakan hasil pemeriksaan rontgen thoraks Distribusi proporsi pasien tuberkulosis paru berdasarkan pemeriksaan Rontgen yang terbanyak adalah luas minimal lesi (46\%), Luas Moderate lesi (37\%), dan Luas far advance lesi (17\%) dapat dilihat pada gambar 2 .

\section{Pemeriksaan Rontgen Thoraks}

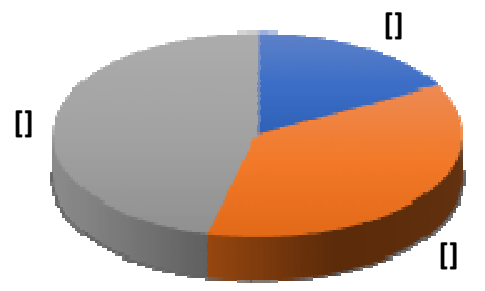

Far Advance Moderate Minimal

Gambar 2. Diagram Bar Distribusi Proporsi pasien DHF Berdasarkan Pemerisaan Rontgen Thoraks yang Dirawat di RS Grandmed Tahun 2019.

Berdasarkan derajat American Thoracic Society dan National Tuberculosis Association, hasil dari pemeriksaan rontgen thoraks menunjukan gambaran luas lesi paru dengan lesi minimal ${ }^{(15)}$.

Hal ini hampir sesuai dengan penelitian yang dilakukan oleh Nova Triandini dkk, tentang Hubungan Hasil Pemeriksaan Sputum Basil Tahan Asam dengan Gambaran Luas Lesi Radiologi Tuberkulosis Paru di Rumah Sakit Al Islam Bandung, pada 101 pasien postif tuberkulosis terdapat 46 pasien $(45,5 \%)$ lesi minimal, 35 pasien $(34,7 \%)$ moderate dan paling sedikit 20 pasien $(19,8 \%)$ far advanced ${ }^{(14)}$.

Penelitian ini juga sejalan dengan hasil yang didapat oleh Muhammad Fikri Husein dkk, tentang Asosiasi Gambaran Tingkat Lesi Foto Toraks Penderita Klinis Tuberkulosis Paru dengan Diabetes Melitus Dibandingkan NonDiabetes Melitus, dimana mayoritas pasien lesi minimal $(53,1 \%)$, moderat $(28,1 \%)$, dan lanjut $(18,8 \%)^{(16)}$.

Distribusi proporsi pasien tuberkulosis paru berdasarkan penyakit penyerta, terbanyak adalah Diabetes (17\%), Pneumonia (14\%), Gastritis (8\%) serta yang terkecil adalah PPOK (1\%), Gagal Ginjal Kronik (1\%).

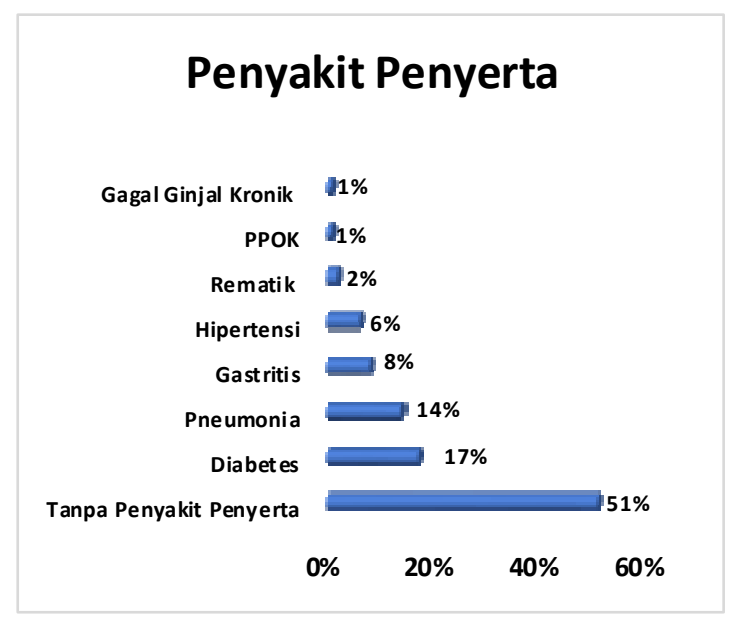

\section{SIMPULAN}

Berdasarkan penelitian yang dilakukan, disimpulkan bahwa:

1. Jenis kelamin pasien tuberkulosis paru terbanyak adalah laki-laki (66\%).

2. Umur pasien tuberkulosis paru terbanyak umur 33-40 tahun (30\%).

3. Gejala utama utama batuk $>2$ minggu (100\%) ditemukan disemua pasien tuberkulosis paru.

4. Gejala tambahan kombinasi terbanyak pada pasien tuberkulosis paru yaitu demam + berkeringat malam hari + penurunan berat badan (37\%).

5. Distribusi hasil pemeriksaan BTA terbanyak postif 1 (33\%).

6. Distiribusi hasil pemeriksaan rontgen thoraks terbanyak adalah lesi minimal (47\%).

7. Distribusi penyakit penyerta pada pasien tuberkulosis paru terbanyak diabetes (17\%).

\section{SARAN}

Saran yang dapat disampaikan penulis dalam penelitian ini adalah sebagai berikut:

1. Untuk instansi pemerintah terutama dinas kesehatan untuk sosialisasi ke daerah- daerah serta pencatatan pelaporan agar mampu memberikan penilain terhadap hasil pengobatan pasien dan kinerja program secara keseluruhan.

2. Bagi peneliti lain, peneliti berharap dapat dilakukan penelitian lebih lanjut dengan variabel yang lebih banyak agar lebih sempurna 
Jurnal Ilmiah Mahasiswa Kesehatan Masyarakat

Vol. 5/No.4 /Oktober 2020; ISSN:2502-731X

DAFTAR PUSTAKA

1. Butarbutar MH. Hubungan Perilaku Dan Sanitasi Lingkungan Dengan Pasien Tb Paru. 2018;1(1):51-61.

2. Anggraeni DE, Rahayu SR. Gejala Klinis Tuberkulosis Pada Keluarga Penderita Tuberkulosis BTA Positif. HIGEIA J Public Heal Home Environ Heal Saf [Internet]. 2018;2(1):91101. Available from: http://journal.unnes.ac.id/sju/index.php/higeia/ article/view/18100

3. Setiawan G, Juniarti N, Yani DI. Hubungan Gaya Hidup Dengan Kejadian Tb Paru Pada Remaja: Kajian Literatur Sistematis. J Keperawatan Komprehensif. 2019;5(1):10.

4. Tristiana RD, Kumalasari R, Makhfudli. Pengalaman Klien TB Paru yang Menjalani Pengobatan Fase Intensif di Puskesmas Taji Kabupaten Magetan. J Keperawatan Komunitas. 2019;8(1):1-10.

5. Dinas Kesehatan Provinsi Sumatera Utara. Profil Kesehatan Provinsi Sumatera Utara Tahun 2017. 2018 Dec;58(12):7250-7.

6. Aini N, Hatta HR. Sistem pakar pendiagnosa penyakit tuberkulosis. 2017;12(1):56-63.

7. Menkes RI. Permenkes RI Nomor 67 Tahun 2016 Tentang Penanggulangan Tuberkulosis. 2016;163.

8. Dotulong JFJ, Sapulete MR, Kandou GD. Hubungan faktor risiko umur, jenis kelamin dan kepadatan hunian dengan kejadian penyakit tb paru di desa wori kecamatan wori. J Kedokt Komunitas dan Trop. 2015;3 no 2(april):57-65.

9. Widyastuti SD, Riyanto R, Fauzi M. Gambaran Epidemiologi Penyakit Tuberkolusis Paru (TB Paru) Di Kabupaten Indramayu. J Care. 2018;6(2):102

10. Susilayanti EY, Medison I, Erkadius E. Profil Penderita Penyakit Tuberkulosis Paru BTA Positif yang Ditemukan di BP4 Lubuk Alung periode Januari 2012 - Desember 2012. J Kesehat Andalas. 2014;3(2):151-5.

11. Mohamad RP, Porotu'o J, Homenta H. Hasil diagnostik Mycobacterium tuberculosis pada penderita batuk $\geq 2$ minggu dengan pewarnaan Ziehl-Neelsen di Puskesmas Ranomuut dan Puskesmas Kombos Manado. J e-Biomedik. 2016;4(2).

12. Mardiah A. Skrining Tuberkulosis (Tb) Paru Di Kabupaten Banyumas Provinsi Jawa Tengah. J Kedokt. 2019;4(1):694.

13. Mulyadi, Mudatsir nurlina. Hubungan Tingkat Kepositivan Pemeriksaan Basil Tahan Asam ( BTA ) dengan Gambaran Luas Lesi Radiologi Toraks pada Penderita Tuberkulosis Paru yang Dirawat Di SMF Pulmonologi RSUDZA Banda Aceh. J
Respir Indo. 2011;31(3):133-7.

14. Triandini N, Hadiati DE, Husin UA, Roekmantara T, Masria S. Hubungan Hasil Pemeriksaan Sputum Basil Tahan Asam dengan Gambaran Luas Lesi Radiologi Tuberkulosis Paru di Rumah Sakit Al Islam Bandung. J Integr Kesehat Sains. 2019;1(1):87-91.

15. Edwina I, Soetikno RD, Hikmat IH. HUBUNGAN ANTARA LUAS LESI PADA FOTO TORAKS PENDERITA TB PARU DEWASA YANG MEMILIKI RIWAYAT DIABETES MELITUS DENGAN INDEKS MASSA TUBUH DI RUMAH SAKIT HASAN SADIKIN BANDUNG Correlation of Tuberculosis Lesion Size in Chest Radiographs of Diabetic Adult Patien. J Radiol Indones. 2016;1(Dm):138-44.

16. Husein MF, Majdawati A. Paru dengan Diabetes Melitus Dibandingkan Non Diabetes Melitus Asosiation Lesion Level of Chest X-Ray Imaging in Patient with Clinical Manifestation of Pulmonary Tuberkulosis with Diabetes Mellitus and without Diabetes Mellitus. 2014;14(1):8-14. 